\title{
ANALISIS ANGKA KEMATIAN NEONATAL DI PROVINSI BALI DENGAN PENDEKATAN ANALISIS REGRESI
}

\author{
Ni Wayan Diah Sihmawati ${ }^{1 \S}$, I Wayan Sumarjaya ${ }^{2}$, Made Susilawati ${ }^{3}$ \\ ${ }^{1}$ Program studi Matematika, Fakultas MIPA - Universitas Udayana [Email: diahsihmawati14@gmail.com] \\ ${ }^{2}$ Program studi Matematika, Fakultas MIPA -Universitas Udayana [Email: sumarjaya@ unud.ac.id] \\ ${ }^{3}$ Program studi Matematika, Fakultas MIPA -Universitas Udayana [Email: susilawati.made@gmail.com] \\ ${ }^{\S}$ Corresponding Author
}

\begin{abstract}
Neonatal mortality rate (NMR) is the number of infant death up to 28 days expressed in 1,000 live births in the same year. The aim of this research is to obtain the best model for NMR in Bali and to find significant factors that influence NMR in Bali using multiple linear regression and spatial regression methods. The data used in this study was obtained from the Health Departement in each district in Bali.The result shows that there is no spatial dependence between regions and no interregional heterogeneity. This suggests that spatial regression is not applicable in this study. Hence, we model the NMR using multiple linear regression. Furthermore, we obtained the estimated NMR model in Bali is $\hat{y}=8,78207+1,13069 X_{3}-0,08069 X_{6}$. In conclusion, the factors that influence the NMR are the percentage of babies with low weight $\left(X_{3}\right)$ and percentage of households with a clean and healthy living behavior $\left(X_{6}\right)$.
\end{abstract}

Keywords: Neonatal mortality rate (NMR), Regression analysis, Spatial regression analysis.

\section{PENDAHULUAN}

Peningkatan derajat kesehatan merupakan bagian yang tidak terpisahkan dari pembangunan nasional yang harus terus-menerus diupayakan oleh pemerintah. Selain angka kematian ibu, indikator lain yang juga digunakan sebagai tolok ukur kemajuan hasil pembangunan pada bidang kesehatan adalah angka kematian neonatal (AKN). AKN adalah jumlah kematian usia sampai 28 hari yang dinyatakan dalam 1.000 kelahiran hidup pada tahun yang sama.

Sebaran AKN per kabupaten/kota di Provinsi Bali seperti, Kabupaten Karangasem meningkat 0,95 per 1.000 kelahiran hidup $(\mathrm{KH})$ Kabupaten Buleleng meningkat 1,34 per 1.000 $\mathrm{KH}$, Kota Denpasar meningkat sebesar 0,13 per $1.000 \mathrm{KH}$. Sedangkan di Kabupaten lain terjadi penurunan AKN, sehingga mempengaruhi capaian Provinsi Bali yang menurun dibandingkan tahun 2014 sebesar 0,09 per 1.000 KH. Pada tahun 2014 AKN Provinsi Bali sebesar 4,50 per $1.000 \mathrm{KH}$, sedangkan di tahun
2015 menurun menjadi 4,41 per $1.000 \mathrm{KH}$ (DisKes Bali, 2015).

Tujuan penelitian ini adalah untuk mendeteksi parameter lokal yang dapat menjelaskan variasi spasial dalam hubungan antara kasus kematian neonatal di Provinsi Bali dengan fakror-faktor yang berkontribusi dengan menggunakan model regresi spasial.

\section{TINJAUAN PUSTAKA}

\section{Analisis Regresi}

Analisis regresi merupakan analisis statistika yang digunakan untuk mendapatkan hubungan dan model antara variabel terikat dan satu atau lebih variabel bebas. Adapun model regresi berganda sebagai berikut (Draper dan Smith, 1992):

$Y_{i}=\beta_{0}+\beta_{1} X_{i 1}+\beta_{2} X_{i 2}+\cdots+\beta_{k} X_{i k}+\varepsilon_{i}(1)$ dengan $Y$ merupakan nilai pengamatan variabel terikat; $\beta_{0}, \beta_{1}, \ldots, \beta_{k}$ merupakan koefisien regresi; $X_{1}, X_{2}, \ldots, X_{k}$ merupakan nilai 
pengamatan variabel bebas; $\varepsilon$ merupakan nilai eror regresi dengan asumsi $\varepsilon \sim \operatorname{IIND}\left(0, \sigma^{2}\right)$ dan $i=1,2,3, \ldots n$.

\section{Pendugaan Parameter Analisis Regresi}

Jika diasumsikan $E(\varepsilon)=0$, maka $E(Y)=$ $X \beta$. Bila model regresi linear benar dan $\beta$ merupakan penduga terbaik yaitu dengan penggadaan awal dengan $X^{\prime}$ sehingga didapatkan persamaan sebagai berikut:

$\left(X^{\prime} Y\right)=\left(X^{\prime} X\right) \beta$.

Nilai vektor $\beta$ dapat diduga dengan menggunakan penduga kuadrat terkecil (least square) bagi parameter regresi. Adapun notasi dalam matriks yang dapat dibentuk yaitu sebagai berikut:

$\hat{\beta}=\left(X^{\prime} X\right)^{-1}\left(X^{\prime} Y\right)$

\section{Pengujian Parameter Analisis Regresi}

Pengujian pada regresi linear dilakukan dengan dua cara yaitu pengujian serentak dan pengujian parsial.

\section{Pengujian Serentak}

Hipotesis uji serentak sebagai berikut:

$$
\begin{aligned}
& H_{0}: \beta_{1}=\beta_{2}=\cdots=\beta_{k}=0 \\
& H_{1}: \text { minimal ada satu } \beta_{k} \neq 0
\end{aligned}
$$

Statistik uji serentak sebagai berikut:

$$
\begin{gathered}
F_{\text {hit }}=\frac{\left(\frac{\text { Jumlah Kuadrat Regresi }}{k}\right)}{\frac{\text { Jumlah Kuadrat Residu }}{n-(k+1)}} \\
F_{\text {hit }}=\frac{\frac{\sum_{i=1}^{n}\left(\widehat{Y}_{i}-\bar{Y}\right)^{2}}{k}}{\frac{\sum_{i=1}^{n}\left(Y_{i}-\widehat{Y}_{i}\right)^{2}}{n-(k+1)}}
\end{gathered}
$$

dengan $Y_{i}$ merupakan nilai aktual pada periode ke- $i, \hat{Y}_{i}$ merupakan nilai terhitung dari variabel yang akan diprediksi pada periode ke- $i, k$ merupakan banyaknya parameter regresi, dan $n$ merupakan banyaknya pengamatan. Dengan keputusan tolak $H_{0}$, jika $F_{\text {hit }}$ lebih besar atau sama dengan $F_{\text {tabel }}=F_{\alpha, k, n-(k+1)}$.

\section{Pengujian Parsial}

Uji signifikasi parsial adalah uji untuk mengetahui variabel mana saja yang memengaruhi variabel secara signifikan.

Hipotesis uji parsial sebagai berikut:

$$
\begin{aligned}
& H_{0}: \beta_{k}=0 \\
& H_{1}: \beta_{k} \neq 0
\end{aligned}
$$

Statistik uji parsial sebagai berikut:

$t_{\text {hit }}=\frac{\widehat{\beta}_{k}}{S E\left(\widehat{\beta}_{k}\right)}$

dengan $(S E)^{2}\left(\hat{\beta}_{k}\right)=\left(X^{\prime} X\right)^{-1} M S E \quad, \quad \hat{\beta}_{k}$ merupakan penduga parameter ke- $k$ dan $S E$ merupakan standar deviasi. Dengan keputusan tolak $H_{0}$ jika $\left|t_{h i t}\right|>t_{\frac{\alpha}{2} ; n-(k+1)}$.

\section{Analisis Regresi Spasial}

Model regresi spasial merupakan model regresi yang melibatkan pengaruh spasial. Salah satu pengaruh spasial yaitu autokorelasi spasial. Adanya unsur autokorelasi menyebabkan terbentuknya parameter spasial autoregresif dan moving average, sehingga bentuk proses yang terjadi yaitu sebagai berikut (Anselin, 1988, p.32):

$y=\rho W_{1} y+X \beta+u$

dan

$u=\lambda W_{2} u+\varepsilon$

$\varepsilon \sim N\left(0, \sigma^{2} I\right)$ tidak ada autokorelasi

sehingga model umum yang terbentuk adalah sebagai berikut:

$y=\rho W_{1} y+X \beta+\lambda W_{2} u+\varepsilon$

dengan $y$ merupakan vektor variabel terikat, dengan ukuran $n \times 1, X$ merupakan matriks variabel bebas dengan ukuran $n \times(k+1), \beta$ merupakan vektor parameter koefisien regresi, dengan ukuran $(k+1) \times 1, \quad \rho$ merupakan parameter koefisien lag spasial variabel terikat, $\lambda$ merupakan parameter koefisien lag spasial pada error, $u$ merupakan vektor error pada persamaan (4) berukuran $n \times 1$, $\varepsilon$ merupakan vektor error pada persamaan (5) berukuran $n \times 1$ dan $W_{1}, W_{2}$ merupakan matriks pembobot berukuran $n \times n$, di mana $W_{1}=W_{2}=W$.

\section{Pendugaan Parameter dan Pengujian Signifikansi Regresi Spasial}

Pendugaan parameter pada regresi spasial menggunakan Maximum Likehood Estimation (MLE) (Anselin, 1988, p.61). Pengujian terhadap parameter model regresi spasial yang dilakukan adalah untuk mengetahui peranan variabel bebas dalam model. Untuk menguji parameter $\beta_{j}$ digunakan uji Wald. 


\section{Efek Spasial}

Efek spasial dibedakan menjadi dua bagian yaitu heterogenitas spasial dan dependensi spasial. Heterogenitas spasial ditunjukkan oleh perbedaan sifat antar satu lokasi dengan lokasi lainnya. Pengujian efek spasial dilakukan dengan uji heterogenitas yaitu dengan uji Breusch-Pagan Test (BP Test) (Anselin, 1988, p.13).

Adapun hipotesis dari uji BP Test adalah:

$H_{0}: \sigma_{1}^{2}=\sigma_{2}^{2}=\cdots=\sigma_{n}^{2}=\sigma^{2}$

(homoskedastisitas)

$H_{1}$ : minimal ada satu $\sigma_{i}^{2} \neq \sigma^{2}$

(heterokedastisitas)

Nilai uji BP Test yaitu sebagai berikut:

$$
B P=(1 / 2) f^{T} Z\left(Z^{T} Z\right)^{-1} Z^{T} f \sim \chi_{k}^{2} .
$$

Efek dependensi spasial ditunjukkan oleh kemiripan sifat untuk lokasi yang saling berdekatan. Uji untuk mengetahui spatial dependence di dalam error suatu model adalah dengan menggunakan statistik Moran's I dan Langrange Multiplier (LM) Test (Anselin, 1988).

Adapun hipotesis yang digunakan adalah sebagai berikut:

$H_{0}: I=0$ (tidak ada autokorelasi antar lokasi)

$H_{1}: I \neq 0$ (ada autokorelasi antar lokasi)

\section{Angka Kematian Neonatal}

Angka Kematian Neonatal (AKN) adalah jumlah kematian usia sampai 28 hari yang dinyatakan dalam 1.000 kelahiran hidup pada tahun yang sama (DisKes Bali, 2015).

\section{Pemilihan Model Terbaik}

Pemilihan model terbaik digunakan untuk memperoleh faktor yang paling berpengaruh dalam suatu penelitian. Kriteria pemilihan model terbaik yang digunakan pada penelitian ini adalah Koefisien Determinasi $\left(R^{2}\right)$ dan Akaike Information Criterion (AIC)

\section{METODE PENELITIAN}

Data yang akan digunakan pada penelitian ini adalah data sekunder yang diperoleh dari Dinas Kesehatan di masing-masing kabupaten Provinsi Bali berupa data kematian bayi neonatal disetiap kecamatan di masing-masing kabupaten Provinsi Bali tahun 2015. Variabel yang digunakan adalah variabel terikat (Y) dan variabel bebas $X_{i}$. Variabel-variabel tersebut yaitu persentase jumlah kematian neonatal di Provinsi Bali (Y), persentase bayi berjenis kelamin laki-laki $\left(X_{1}\right)$, persentase bayi berjenis kelamin perempuan $\left(X_{2}\right)$, persentase bayi dengan berat badan rendah $\left(X_{3}\right)$, persentase kunjungan antenatal $3 \mathrm{kali}\left(X_{4}\right)$, persentase ibu hamil dengan melakukan kunjungan $\mathrm{K} 4\left(X_{5}\right)$, persentase rumah tangga berperilaku hidup bersih dan sehat $\left(X_{6}\right)$ dan persentase ibu melahirkan dengan bantuan non medis $\left(X_{7}\right)$.

Langkah-langkah analisis yang akan digunakan dalam penelitian ini adalah sebagai berikut:

1. Mendeskripsikan variabel-variabel penelitian dari sudut kewilayahan dengan menggunakan peta tematik.

2. Uji dependensi spasial dengan menggunakan uji Moran's I pada setiap variabel kemudian membentuk Moran's scatterplot untuk mengetahui penyebaran antarlokasi.

3. Pemodelan Ordinary Least Square (OLS) dengan langkah sebagai berikut:

a. Melakukan pendugaan parameter pada variabel bebas terhadap variabel terikat dan melakukan uji hipotesis signifikansi parameter.

b. Pemeriksaan asumsi residual, untuk mengetahui asumsi residual memenuhi identik, dan berdistribusi normal.

4. Melakukan pemodelan regresi spasial, terdiri dari:

a. Melakukan uji heterogenitas spasial dengan Breusch-Pagan Test pada residual.

b. Melakukan uji dependensi spasial menggunakan uji Lagrange Multiplier (LM) dan uji Moran's I.

c. Melakukan uji signifikansi parameter.

5. Membandingkan hasil analisis OLS dengan metode analisis regresi spasial dengan melakukan pemilihan model terbaik menggunakan kriteria AIC.

6. Interpretasi model 


\section{HASIL DAN PEMBAHASAN}

\section{Identifikasi Model}

Pertama yang dilakukan dalam pemodelan OLS dan regresi spasial yaitu identifikasi pola hubungan antara variabel terikat dan variabel bebas dengan menggunakan Scatterplot. Dari hasil yang diperoleh menunjukkan bahwa ada empat variabel bebas yang berkorelasi negatif terhadap variabel terikat. Variabel tersebut yaitu persentase bayi berjenis kelamin perempuan $\left(X_{2}\right)$, persentase ibu hamil dengan melakukan kunjungan $\mathrm{K} 1\left(X_{4}\right)$, persentase ibu hamil dengan melakukan kunjungan $\mathrm{K} 4\left(X_{5}\right)$ dan persentase ibu mendapatkan tablet fe3 $\left(X_{6}\right)$.

Hal ini berarti semakin tinggi nilai variabel bebas yang berpengaruh maka semakin rendah angka kematian neonatal begitu juga sebaliknya. Sedangkan terdapat empat variabel yang membentuk pola yang menyebar, ini berarti variabel bebas tersebut tidak menunjukkan pola yang jelas terhadap variabel terikat.

\section{Pemodelan Ordinary Least Square (OLS) dan SAR}

\section{1) Pengujian Parameter OLS}

Pengujian OLS dilakukan dengan pengujian serentak dan pengujian parsial.

a.Uji Serentak

Hipotesis uji serentak sebagai berikut:

$H_{0}: \beta_{1}=\beta_{2}=\cdots=\beta_{k}=0$,

$H_{1}$ : minimal ada satu $\beta_{k} \neq 0$.

Pengambilan keputusan dilakukan jika nilai $F_{\text {Hitung }}>F_{0,005 ; 7 ; 56}$,maka keputusan yang diambil adalah tolak $H_{0}$, yang berarti bahwa variabel bebas secara serentak berpengaruh terhadap variabel terikat. Dari hasil pengujian serentak dapat dilihat pada Tabel 1, yang menghasilkan nilai $F_{\text {Hitung }}=3,059$ dan $F_{0,005 ; 7 ; 56}=2,18$ sehingga diperoleh nilai $F_{\text {Hitung }}$ lebih besar daripada nilai $F_{0,005 ; 7 ; 56}$, maka keputusan yang diambil adalah tolak $H_{0}$. Hal ini berarti bahwa variabel bebas secara serentak berpengaruh terhadap variabel terikat.
Tabel 1. Pendugaan Parameter dengan Metode OLS

\begin{tabular}{|cccc|}
\hline & & \multicolumn{2}{c|}{$p$} \\
Parameter & Estimasi & $t_{\text {Hitung }}$ & - value \\
\hline$\beta_{0}$ & 540.78 & 0.99 & 0.325 \\
$\beta_{1}$ & -5.24 & -0.96 & 0.342 \\
$\beta_{2}$ & -5.36 & -0.98 & 0.334 \\
$\beta_{3}$ & 1.10 & 3.48 & $0.001^{*}$ \\
$\beta_{4}$ & 0.03 & 0.34 & 0.736 \\
$\beta_{5}$ & -0.06 & -0.73 & 0.469 \\
$\beta_{6}$ & -0.08 & -2.05 & $0.045^{*}$ \\
$\beta_{7}$ & 0.02 & 0.15 & 0.879 \\
\hline R-Square & & & $20.76 \%$ \\
$F_{\text {Hitung }}$ & & & 3.059 \\
\hline
\end{tabular}

Sumber: data diolah 2018

b. Uji Parsial

Hipotesis uji parsial sebagai berikut:

$H_{0}: \beta_{k}=0$,

$H_{1}: \beta_{k} \neq 0$.

Pengambilan keputusan dilakukan jika nilai $\left|t_{\text {Hitung }}\right|>t_{\text {0,025;7;56 }}$,maka keputusan yang diambil adalah tolak $H_{0}$, yang berarti bahwa variabel bebas berpengaruh terhadap variabel terikat.

Oleh karena ada dua variabel yang signifikan dilakukan pendugaan parameter ulang pada kedua variabel yang signifikan tersebut untuk dibandingkan dengan metode SAR, maka hasil pendugaan dengan OLS dapat dilihat pada Tabel 2.

Tabel 2. Pendugaan Parameter Dua Variabel dengan Metode OLS

\begin{tabular}{|llll|}
\hline Parameter & Estimasi & $t_{\text {Hitung }}$ value $^{p-}$ \\
\hline$\beta_{0}$ & 8.78207 & 2.863 & 0.006001 \\
$\beta_{3}$ & 1.13069 & 3.713 & 0.000493 \\
$\beta_{6}$ & -0.08069 & -2.122 & 0.038547 \\
\hline R-Square & & & \\
$F_{\text {Hitung }}$ & & & $27.15 \%$ \\
\end{tabular}

Sumber: data diolah 2018

maka model yang terbentuk sebagai berikut:

$\hat{y}=8,78207+1,13069 X_{3}-0,08069 X_{6}$

Interprestasi dari model tersebut yaitu apabila persentase bayi dengan berat badan rendah 
bertambah sebanyak satu satuan maka kematian neonatal akan cenderung bertambah sebanyak 8,78207 kali dengan asumsi variabel yang lain konstan, apabila persentase rumah tangga dengan berperilaku hidup bersih dan sehat bertambah satu satuan maka akan cenderung mengurangi kematian neonatal sebanyak 0,08069 kali dengan asumsi variabel yang lain konstan.

Intersep 8,78207 artinya kematian neonatal pada bayi sebesar 8,78207 , apabila tidak terdapat faktor-faktor yang memengaruhi kematian neonatal seperti persentase bayi dengan berat badan rendah dan persentase rumah tangga dengan berperilaku hidup bersih dan sehat. Setelah mendapatkan model OLS selanjutnya dilakukan pengujian asumsi residual.

Nilai Moran's I pada residual sebesar 0.017516118 di mana menghasilan nilai yang lebih besar dari nilai $I_{0}=-0,01818182$, maka dapat diindikasi terdapat pengelompokkan residual.

\section{2) Uji Dependensi Spasial}

Uji dependenssi spasial dilakukan untuk mengidentifikasi apakah ada hubungan antarlokasi terhadap masing-masing variabel. Uji dependensi spasial dilakukan dengan nilai Moran's I.

Adapun hipotesis yang digunakan yaitu: $H_{0}: I=0$ (tidak ada autokorelasi antarlokasi), $H_{1}: I \neq 0$ (ada autokorelasi antarlokasi), dengan pengambilan keputusan tolak $H_{0}$ atau terdapat dependensi spasial apabila $\left|Z_{\text {hitung }}\right|>Z_{\alpha / 2}$.

Tabel 3 Pengujian Moran's I

\begin{tabular}{|c|l|c|}
\hline Kode & Moran's I & $\left|Z_{\text {hitung }}\right|$ \\
\hline $\mathrm{Y}$ & $-0,24573423$ & 0,84315289 \\
\hline$X_{1}$ & 0,03953867 & 0,21387246 \\
\hline$X_{2}$ & 0,03576633 & 0,19989476 \\
\hline$X_{3}$ & $-0,03430690$ & 0,05974849 \\
\hline$X_{4}$ & 0.01172620 & 0,11081855 \\
\hline$X_{5}$ & 0,01130341 & 0,10925201 \\
\hline$X_{6}$ & $-0,32198461$ & 1,12568439 \\
\hline$X_{7}$ & $-0,04530546$ & 0,10050158 \\
\hline
\end{tabular}

Sumber: data diolah 2018

Ket: signifikan pada $\alpha=5 \% ; Z_{0,025}=1,96$
Berdasarkan hasil pengujian $\left|Z_{\text {hitung }}\right|$ dengan signifikansi 5\% seperti pada Tabel 3, maka pengambilan keputusan yang diambil adalah terima $H_{0}$ yang berarti tidak ada kebergantungan atau dependensi spasial untuk setiap kecamatan.

\section{3) Uji Breusch-Pagan Test (BP Test)}

Pada pengujian heterogenitas spasial dilakukan dengan uji Breusch-Pagan Test (BP Test). Hipotesis yang digunakan sebagai berikut:

$$
H_{0}: \sigma_{1}^{2}=\sigma_{2}^{2}=\cdots=\sigma_{n}^{2}=\sigma^{2}
$$

(homoskedastisitas), dan

$H_{1}:$ minimal ada satu $\sigma_{i}^{2} \neq \sigma^{2}$ (heterokedastisitas) .

Pengambilan keputusan dilakukan jika $\mathrm{BP}>\chi_{\alpha, k}^{2}$ atau $\mathrm{p}$-value $<\alpha$, maka $\mathrm{H}_{0}$ ditolak yang berarti bahwa ada heterogenitas spasial antardaerah.Hasil pengujian heterogenitas spasial disajikan pada Tabel 4.

Tabel 4. Uji Heterogenitas Spasial BreuschPagan Test

\begin{tabular}{|l|l|l|l|}
\hline Uji & DF & Nilai & Prob. \\
\hline $\begin{array}{l}\text { Breusch-Pagan } \\
\text { Test }\end{array}$ & 7 & 3.2637 & 0.8596 \\
\hline
\end{tabular}

Sumber: data diolah 2018

Berdasarkan Tabel 4 didapatkan nilai BreuschPagan Test sebesar 3,2637dan p-value sebesar 0,8596 . P-value yang diperoleh lebih besar dari $\alpha=0,05$. Keputusan yang diambil adalah terima $\mathrm{H}_{0}$, yang berarti bahwa tidak ada adanya heterogenitas spasial antardaerah. Karena pada kasus ini tidak ada kebergantungan spasial antardaerah dan tidak ada heterogenitas spasial antardaerah, maka kurang tepat digunakan metode regresi spasial.

\section{KESIMPULAN}

Berdasarkan hasil dan pembahasan penyebaran kasus kematian neonatal di Provinsi Bali tahun 2015, tidak terdapat kebergantungan spasial antardaerah dan heterogenitas spasial antardaerah, sehingga pemodelan hanya menggunakan metode regresi sederhana. Model 
regresi sederhana yang terbentuk untuk memodelkan penyebaran kasus angka kematian neonatal di Provinsi Bali pada tahun 2015 yaitu $\hat{y}=8,78207+1,13069 X_{3}-0,08069 X_{6}$.

Faktor yang memengaruhi penyebaran kasus angka kematian neonatal di Provinsi Bali yaitu persentase bayi dengan berat badan rendah dan persentase rumah tangga dengan berperilaku hidup bersih dan sehat. Pada penelitian ini banyak faktor yang tidak signitifikan. Untuk penelitian selanjutnya diharapkan menambah faktor-faktor yang memengaruhi kematian neonatal lainnya.

\section{DAFTAR PUSTAKA}

Anselin, Luc. (1988). Spatial Econometrics:Medhods and Model. California: Dordretht : Kluer Academic Publishers.

Dinas Kesehatan. (2016). Profil Kesehatan Provinsi Bali Tahun 2015. Bali: Profil Kesehatan Provinsi Bali Tahun 2016.

Draper, N. dan Smith. (1992). Analisis Regresi Terapan. Edisi Kedua. Jakarta: Gramedia Pustaka Utama. 